\title{
Reação em Cadeia da Polimerase em Embriōes Bovinos para Treinamento
}

Autor: Carlos Gilberto Almodin

Orientador: Prof. Dr. Antonio Fernandes Moron

Co-orientador: Prof. Dr. Luiz Kulay Júnior

Apresentada ao Departamento de Obstetrícia da Universidade Federal de São Paulo - Escola Paulista de Medicina para obtenção do Título de Doutor em Medicina, em 29 de julho de 2002.

Objetivos: Desenvolvimento de um protocolo animal para aprimoramento técnico do pessoal interessado em adquirir conhecimentos em reação em cadeia da polimerase (PCR).

Métodos: Ovários de vaca obtidos em abatedouro eram puncionados e os ovócitos encontrados eram maturados e submetidos à fertilização in vitro. No dia 3 pós-fertilização, os embriões eram biopsiados, com abertura mecânica da zona pelúcida, sendo 1 a 2 blastômeros removidos. Os blastômeros removidos ou o restante do embrião eram submetidos ao PCR para determinação do sexo. Para a amplificação, 2 pares de "primers" foram usados, um externo e outro interno (PCR "nested"). O produto do PCR "nested" foi submetido à ação da enzima de restrição PstI, que "corta" regiões específicas para sexagem.

Resultados: Foram analisados 50 embriões e 50 blastômeros biopsiados destes embriões, submetidos à amplificação de DNA para sexagem. Dos 50 embriões avaliados, 41 (82\%) amplificaram o DNA e 9 (18\%) não amplificaram. Das 50 biópsias realizadas, 31 (62\%) amostras amplificaram e 19 (38\%) não amplificaram. Dos 41 embriões que amplificaram, 27 (65,9\%) eram fêmeas e $14(34,1 \%)$ machos. Em 40 (80\%) dos casos, tantos os embriões como as amostras amplificaram e foi possível identificar o sexo e sempre foi concordante.

Conclusão: O menor numero de amplificação nas biopsias ocorreu devido à dificuldade no manuseio das amostras, provavelmente houve perda de algumas não tornando possivel sua amplificação. A concordância dos resultados em $80 \%$ dos casos mostra que não houve contaminação com DNA estranho. Através desta técnica podem-se encontrar os erros e aprimorar o desempenho.

Palavras-chave: Reação em cadeia da polimerase. Embriões bovinos. Treinamento.

\section{Curva de Probabilidade para o Parto Prematuro Espontâneo de Acordo com o Compri- mento do Colo Uterino Avaliado pela Ultra-sonografia Transvaginal}

Autor: Mário Henrique Burlacchini de Carvalho

Orientador: Prof. Dr. Roberto Eduardo Bittar

Tese de Doutorado em Medicina apresentada ao Programa de Pós-graduação em Obstetrícia e Ginecologia da Faculdade de Medicina da Universidade de São Paulo, em 22 de maio de 2003.

O objetivo do estudo foi construir curva de probabilidade para o parto prematuro, com idade gestacional menor que 37 e menor ou igual a 34 semanas, baseado no comprimento do colo uterino pela ultra-sonografia transvaginal. Foram avaliadas 1958 gestantes da população geral, entre 21 e 24 semanas, sem sintomas de trabalho de parto prematuro. A incidência de parto com IG $<37$ semanas foi de $8,9 \%$ e com IG $<34$ semanas, de $3,4 \%$. A média do comprimento do colo uterino foi de $35,3 \mathrm{~mm}( \pm 8,9 \mathrm{~mm})$. Quanto menor o comprimento do colo uterino, menor a idade gestacional média do parto, sendo de 33,3 semanas quando este media 15 $\mathrm{mm}$ ou menos e de 38 semanas, quando media $30 \mathrm{~mm}$ ou menos. Em relação ao parto com IG $<37$ semanas, o comprimento do colo uterino menor ou igual a 20 $\mathrm{mm}$ teve sensibilidade de $26,9 \%$ para uma taxa de falso-positivo de 1,9\%. A média do comprimento do colo, entre as gestantes com parto prematuro, foi de 28,1 $\mathrm{mm}$ e, entre as gestantes com parto a termo, foi de 36 $\mathrm{mm}(\mathrm{p}<0,0001)$. Em relação ao parto com $\mathrm{IG}<34$ semanas, o comprimento do colo uterino teve sensibilidade de $51,5 \%$ e falso-positivo de $2,5 \%$. A média do comprimento do colo uterino, entre as gestantes que evoluíram com parto com $\mathrm{IG}<34$ semanas, foi de $23,8 \mathrm{~mm}$ e de $35,6 \mathrm{~mm}$ nas gestantes com parto com IG $>34$ semanas $(p<0,0001)$. O melhor ponto de corte do colo uterino para predição do parto com IG $<37$ semanas e IG $<34$ semanas foi de $20 \mathrm{~mm}$. Pelo modelo de regressão logística multivariada, foi possivel construir curvas de probabilidade para o parto com IG $<37$ semanas e IG < 34 semanas, baseado no comprimento do colo uterino, afunilamento e antecedente de prematuridade. 